\title{
Conceptualizing the Practicum Experience of Pre-Service English Language Teachers through Reflection
}

\author{
Yvonne Pedria Velasco \\ Carlos Hilado Memorial State College \\ Talisay City, Negros Occidental \\ Philippines
}

\begin{abstract}
This study inferred the pre-service English teachers conceptualizations of their internship experience and investigated the process of reflective identity construction. Thirty pre-service English language teachers participated in the study with their final reflection reports comprising the data analysed in the study. Through a process of analysis that made use of communication units, the findings suggest that the pre-service language teachers indicated a positive impression of their practicum experience evidenced by their use of positive evaluative remarks. The interns also reported that they have improved cognitively in the duration of their practicum. The interns' reflective practices offered the teacher interns an opportunity to conceptualize their roles as second language teachers and may well raise their awareness about second language teaching in general.
\end{abstract}

Keywords: pre-service second language teacher; practicum experience; reflective identity construction; teacher's beliefs; communication units.

\section{Introduction}

The goal of any Second Language Teacher Education Program is to provide teachers with theories in linguistics, language learning, teaching ideas, psychology and so on. Besides building a theoretical base for the would-be teacher, the pre-service programs afford the teacher interns a range of teaching experiences they can acculturate into their profession. The variety of teaching techniques is best experienced during practicum courses that help shape teacher training by learning theory taken from study and research and translate or apply it in practice.

Yet, besides making available to the pre-service teachers a solid knowledge base and affording them the opportunity to apply the theoretical knowledge into practice during practicum, the longer-term goal for a Second Language Teacher Education Program is to facilitate a pre-service teacher's 
general understanding of the teaching profession and reflect on his/her identity and role as a teacher. Goker (2006) sees the process more as a bottom-up exercise that involves having to examine the many facets of one's practice to serve as a guide for a thoughtful assessment.

By examining in retrospect one's teaching, i.e., lesson planning, portfolio making, doing classroom research, interacting with cooperating teachers and supervisors and students, demonstration teaching, in short, looking back and reflecting on previous experiences, a teacher actively constructs knowledge and not just passively receives it. Essentially, reflecting on past experiences and developing one's belief systems are actively constructing knowledge. While it is vital in mainstream educational research to look into teachers' beliefs generally, it is equally important to explore the instructional circumstances with which second language teachers are situated to provide insight into how these teachers make instructional decisions and essentially explore how English language interns make of their practicum experience as a whole.

The present study is situated against this backdrop. It places the English language interns' reflections of their practicum experience and bringing their beliefs about it into focus. Johnson (1994) intimates that comprehending how teacher beliefs impact teaching practices is essential to the over-all operation of teacher education programs.

\section{Review of Related Literature}

Some concepts and findings from relevant work are outlined below to help inform the present study. These topics clustered around practicum placements, teachers' beliefs, reflective practices and identity construction.

\section{Practicum placements}

Practicum is "one of the biggest influences of the teacher education course" in terms of teacher development (Farrell, 2008, cited in Trent, 2010 p.227). It offers teacher-interns a space to witness real teachers, students, and curriculum at work in natural settings. Spooner-Lane et al. (2009) emphasize that practicum helps interns learn the rigors of teaching and furthermore teaches them to manage the demands associated with it. By engaging in dialogues with their supervisors, interns are able to arrive at a contextualized understanding of the complexities of teaching.

Trent (2010) looks at practice teaching as a crucial aspect of a teacher education program. During practicum, teacher-interns obtain relevant classroom experience, translate theory to practice, expand their awareness about goal setting and reflect on teaching and learning philosophies (Gebhard, 2009).

Hence, teacher education programs face the challenge of creating the instructional conditions that would afford pre-service English teachers the opportunities to connect theoretical knowledge to their experiential knowledge in their journey towards becoming professional second language teachers. In this regard, the field is ripe to undertake educational research to thresh out issues whereby it is assumed that pre-service teachers who have had exposure to various pedagogical approaches in their college courses will be able to translate such to the school settings where they will eventually teach. 


\section{Teachers' beliefs}

Teachers' beliefs and perceptions have been the main focus of most studies conducted on learning to teach (Chiang, 2003; Fives, 2003; Johnson, 1994; Raths \& McAninch, 2003; cited in Hudson et al., 2008). Studies report that despite course work and practicum experience, teacher-interns' beliefs about teachers and teaching are unaffected (McDaniel, 1991; McLaughlin, 1991; Weinstein, 1990 cited in Johnson, 1994). On the other hand, Johnson (1994) explored the connection between pre-service EFL teachers' beliefs about teachers and teaching, and their perceptions of their practicum experience and found that practicum experiences influence the pre-service EFL teachers' image of themselves as teachers and their opinions of their instructional practices. This finding is consistent with the results in the study of Pajares (1992) and VelezRendon (2006) that highlighted the impact of pre-service experiences and beliefs for developing teaching practices (Hudson et al., 2008).

\section{Reflective practices}

The reflective practices of pre-service teachers during their practicum experiences have been gaining ground in research in recent years (Merc, 2010). For instance, Farrell (1999) explored the reflective practices of EFL teachers in Korea to determine the emerging topics in their weekly meetings to identify whether the reflection level is critical or descriptive and to determine if this level changes over time.

Likewise, Liou (2001) studied the reflective practices of pre-service Taiwanese English teachers and found that they need lower affective states, as well as, training on reflectivity and teacher development group meetings to help foster positive change and reflectivity in teaching. The finding further suggests that teachers' awareness of their teaching results from critical reflection.

In a professional setting, critical reflection fosters effective teacher interaction by influencing the way teachers take a stand by challenging other people's assumptions that ultimately leads towards an improvement in teaching practices (Carr \& Kemmis, 1983; Manouchehri, 2002; Burnett \& Lingam, 2007; cited in Yang, 2009).

Reflective practices prospectively provide English teacher-interns a way to conceptualize their roles as second language teachers and may well raise their awareness about second language teaching in general.

\section{Identity construction}

By reflecting on the pre-service teachers' values, beliefs, and philosophies emphasizing awareness and questioning, practicum experience is viewed more as a crucial part of teacher identity construction rather than a transfer of knowledge and skills (Danielewics, 2001, cited in Trent, 2010, p.10). Hence, teaching may be perceived more as an identity rather than as a role in the problem-solution framework (Berci, 2007). 
Gebhard (2009) emphasizes that identity construction facilitates preservice teachers' understanding of how their practicum experiences inform teaching.

In summary, teachers' beliefs and reflective practices are crucial in teacher education within the framework of the pre-service English language teachers' practicum experience. Teacher-interns think critically and reflectively allowing them to conceptualize their practicum experiences and construct their identities as second language teachers and the roles they play in second language teaching as a result of these processes. Moreover, these processes may well enable them to go into teaching with the capability to continuously develop as professionals that would, in turn, likely contribute to making second language instruction effective.

\section{Theoretical framework}

The Theory of Constructivism informs the present study. Constructivism as a theory is a reaction to didactic approaches such as behaviourism and programmed instruction and posits that knowledge is constructed based on personal experiences and hypotheses of the environment.

In the present study, the interns actively construct knowledge of themselves as second language teachers by bringing and contextualizing their past experiences and by making hypotheses of their lived experiences through a reflection of their two-semester practicum experience.

Moreover, this paper also draws upon Fairclough's (2003) model of identity formation (cited in Trent, 2010) that argues "what people commit themselves to in texts is an important part of how they identify themselves, the texturing of identity" (p.164).

As pioneers of the extended practicum course of two semesters, it is assumed that the interns would be able to bring their experiences from the practicum and interweave those with their theoretical knowledge received in the college to ultimately construct their knowledge of themselves and of the roles that they play in the society that they live. The final reflection reports that they wrote after their two-semester practicum experience serves as the data source for inference.

\section{Research Questions}

The present study investigated the English language interns' conceptualization of their practicum experience and their reflective identity construction as second language teachers.

Specifically, this study answers the following questions:

1. What is the general impression of the English language teacher-student interns of their practicum experience?

2. What were the significant cognitive and emotional milestones indicative of growth as perceived by the English Language teacher interns?

3. How practical was the pre-service training received by the interns as an indicator for integration in their English language teaching practicum experience? 


\section{Methodology}

This section discusses the research design, the setting, the participants of the study and the instrument used. The procedure in data collection and analysis of data are likewise discussed.

\section{Research Design}

The study uses a cross-sectional descriptive research design to explore the English language interns' conceptualization of their practicum experiences and their reflective identity construction as second language teachers. This design is appropriate as it seeks to explain the nature of the second language teacher preparation program, particularly, the practicum component, as perceived by a group of graduating interns who were pioneers of the two-semester-practicum teaching course.

\section{Setting}

The present study was set at a higher education institution, a state college, quite known in Negros Occidental, Philippines for its Teacher Education Program that has consistently produced graduates of its teacher education programs who have successfully passed the Licensure Examinations for Teachers (LET). The institution has previously held the record for being number one in the whole province for the highest percentage of LET passers. It is from this setting that the participants of the study were selected.

\section{Participants}

The participants were 35 (9 male and 26 female) pre-service English teachers. All participants were 4th-year students taking up Bachelor of Secondary Education, major in English. During the fifteen weeks of intensive course work in the first semester, the pre-service teachers completed four days of classroom observations, understanding the school's organizational structure and policies. They engaged in 56 consecutive days of classroom observation and practice teaching after that.

In the second semester, the pre-service teachers completed fifty-six consecutive days being increasingly involved in classroom activity. The interns moved from observations to engaging with individual students and small groups before teaching whole lessons to classes. In the teaching practicum, the pre-service teachers received feedback from their supervisor at least a day before their teaching experience. Their cooperating teachers likewise gave feedback on their teaching immediately after their teaching demonstrations. There were also feedback sessions held every Friday to process and reflect on problems met and best practices observed during the practicum week with the college supervisor. Necessarily, the pre-service teachers were required to undergo teaching reflections and submit reflection reports to their college supervisor. 


\section{Instruments}

The final reflection journals containing the reports of the pre-service teachers were used to form the data of this study. There is a periodic reflection report submitted by the pre-service teachers, one for each week for fifteen weeks. However, for this study, only the final reflection reports were considered to gather the needed data since the relevant reflection reports/journals narrate about the pre-service teachers' practicum experience in its entirety (two semesters).

\section{Procedure}

After due consideration, and with consent duly acquired, approval of the subject specialist/supervisor of the pre-service teachers to work on this study was obtained. It was deliberated that the final reflection reports would best represent the instrument from which data shall be culled.

There were 35 pre-service teachers enrolled in the program, but only 30 reflection reports were successfully obtained because the other five participants did not meet the deadline due to some reasonable delays. Although the remaining five final reports were eventually submitted, they were no longer considered for this study.

\section{Data Analysis}

The present study is descriptive. Descriptive research helps researchers understand a phenomenon of interest, generate hypotheses and intervention, interpret findings, diagnose problems, and identify new issues to study (Loeb et.al., 2017). Through Glaser \& Strauss' (1967) Constant Comparative Method of analysis (cited in Merc, 2010), analyses of the data occurred iteratively as the researcher, working with the supervisor, moved between the data and the practicum experience/reflective thinking research literature. The Constant Comparative Method is a method for analyzing data in order to develop a grounded theory to explain social phenomena. Creswell (2003) defines grounded theory research as one where the "researcher attempts to derive a general, abstract theory of a process, action, or interaction grounded in the views of participants in a study"(p. 14).

Likewise, Fairclough's (2003) framework for evaluation (cited in Trent, 2010) was used as a method of analysis. Evaluation is a description of desirability expressed in terms of usefulness or utility or whether one thing is considered good or bad. While evaluations maybe overt, they may also be covertly embedded in texts.

The analysis of the reflection reports used communication units as a form of analysis. Mangelsdorf (1992) defines a communication unit as "a unit being a separate expression about a thought or behaviour" (cited in Merc, 2010, p.276). They appear as a phrase, or a full sentence; or, a paragraph or a set of paragraphs (Merc, 2010).

Communication units were determined according to the perceptions and general impressions of the pre-service English teachers of their two-semester practicum experience. These communication units were compared and 
contrasted with each other. The ones that show similar characteristics were assigned to categories and subcategories. The categories are named by ascribing to them the general characteristic of the set. Finally, a consultation meeting was conducted to decide on the themes that ultimately emerged.

\section{Results}

The analysis of data allowed the use of perspectives, in the form of impressions and beliefs, of English teacher-interns to conceptualize their practicum experience and to demonstrate an identity construction out of the perceptions they have of themselves and second language teaching.

\section{General impression of the practicum experience}

Of the three main categories drawn, a general impression of the practicum experience was mentioned by $100 \%$ of the participants. Their general impression was coded as a communication unit when it describes their over-all experience during the entire practicum. The general impression is further divided into two sub-categories: positive and negative impression. An impression is coded as positive when the communication unit largely evokes positive feelings of recollection; it is coded as negative when the communication unit largely evokes negative feelings of recollection. The main category of the general impression of the practicum experience and the sub-categories are presented in Table 1 below.

Table 1. General impressions of the pre-service English teachers of their practicum experience

\begin{tabular}{|c|c|c|c|}
\hline \multicolumn{2}{|c|}{ Category } & Sub-categories & $N$ \\
\hline \multirow{14}{*}{$\begin{array}{l}\text { General } \\
\text { impression of } \\
\text { the practicum } \\
\text { experience }\end{array}$} & \multirow{10}{*}{$\begin{array}{l}\text { Positive } \\
\text { impression }\end{array}$} & $\begin{array}{l}\text { Best thing that ever happened in } \\
\text { my life }\end{array}$ & 2 \\
\hline & & $\begin{array}{l}\text { Most significant part of my } \\
\text { education }\end{array}$ & 1 \\
\hline & & It was beyond expectations & 1 \\
\hline & & $\begin{array}{l}\text { A gigantic factory producing } \\
\text { competitive teachers }\end{array}$ & 1 \\
\hline & & Provided the best training & 3 \\
\hline & & $\begin{array}{l}\text { Grounded one to be an excellent } \\
\text { student-teacher }\end{array}$ & 1 \\
\hline & & Prepared me well & 5 \\
\hline & & Made me ready for teaching & 2 \\
\hline & & $\begin{array}{l}\text { Taught me everything I needed } \\
\text { to know }\end{array}$ & 1 \\
\hline & & $\begin{array}{l}\text { A great combination of fun and } \\
\text { adventure }\end{array}$ & 1 \\
\hline & \multirow{4}{*}{$\begin{array}{l}\text { Negative } \\
\text { impression }\end{array}$} & Subtotal & 18 \\
\hline & & Always felt nervous in the field & 2 \\
\hline & & Stressful/Tiresome experience & 2 \\
\hline & & Wasn't easy/Difficult & 1 \\
\hline
\end{tabular}




\begin{tabular}{|l|l|c|}
\hline \multirow{4}{*}{} & experience & \\
\cline { 3 - 3 } & Uncertain/unsure of self & 1 \\
\cline { 2 - 3 } & Made me anxious & 3 \\
\cline { 2 - 3 } & Harsh journey/full of trials & 3 \\
\hline \multicolumn{2}{|r}{ Subtotal } & 12 \\
\hline
\end{tabular}

$N=$ communication units

Of the 30 interns, $18(60 \%)$ gave a positive impression about their practicum experience, while 12 participants $(40 \%)$ gave a negative impression about their practicum experience. Of the positive impressions counted, "prepared me well" as a sub-category has the highest frequency $(\mathrm{N}=5)$; while of the negative impressions, "harsh journey" and "made me anxious" received an equal number of occurrence $(\mathrm{N}=3)$.

\section{Self-perceived significant growth during the practicum}

The analysis of the final reflection reports revealed a category on self-perceived significant growth of the English teacher-interns during their practicum as shown in Table 2 below. The emergent category of significant cognitive and emotional milestones indicative of growth as pre-service English teachers were identified by ascribing a communication unit that pertains to the self, which the pre-service English teachers perceived as a significant indication of growth and development during their practicum experience.

Table 2. Self-perceived significant growth of the pre-service English teachers during their practicum experience

\begin{tabular}{|c|c|c|c|}
\hline Category & & Sub-categories & $N$ \\
\hline \multirow{18}{*}{$\begin{array}{l}\text { Self-perceived } \\
\text { significant } \\
\text { milestones } \\
\text { indicative of } \\
\text { growth as pre- } \\
\text { service English } \\
\text { teachers }\end{array}$} & \multirow{7}{*}{ Cognitive } & $\begin{array}{l}\text { Intellectual preparedness/mastery } \\
\text { of lessons }\end{array}$ & 10 \\
\hline & & $\begin{array}{l}\text { Application of teaching principles } \\
\text { and strategies }\end{array}$ & 17 \\
\hline & & Practice classroom skills & 2 \\
\hline & & Better in assessment & 1 \\
\hline & & $\begin{array}{l}\text { Understand social structures and } \\
\text { people's behaviour }\end{array}$ & 1 \\
\hline & & Classroom Management & 2 \\
\hline & & Time Management & 2 \\
\hline & \multicolumn{2}{|r|}{ Subtotal } & 35 \\
\hline & \multirow{10}{*}{ Emotional } & Appreciative & 5 \\
\hline & & Confident & 9 \\
\hline & & Creative & 2 \\
\hline & & Flexible & 3 \\
\hline & & Hardworking & 3 \\
\hline & & Humility (to admit I don't know) & 3 \\
\hline & & Handle students well & 2 \\
\hline & & Love teaching/students & 4 \\
\hline & & Motivated & 4 \\
\hline & & Obedient/Submissive & 4 \\
\hline
\end{tabular}




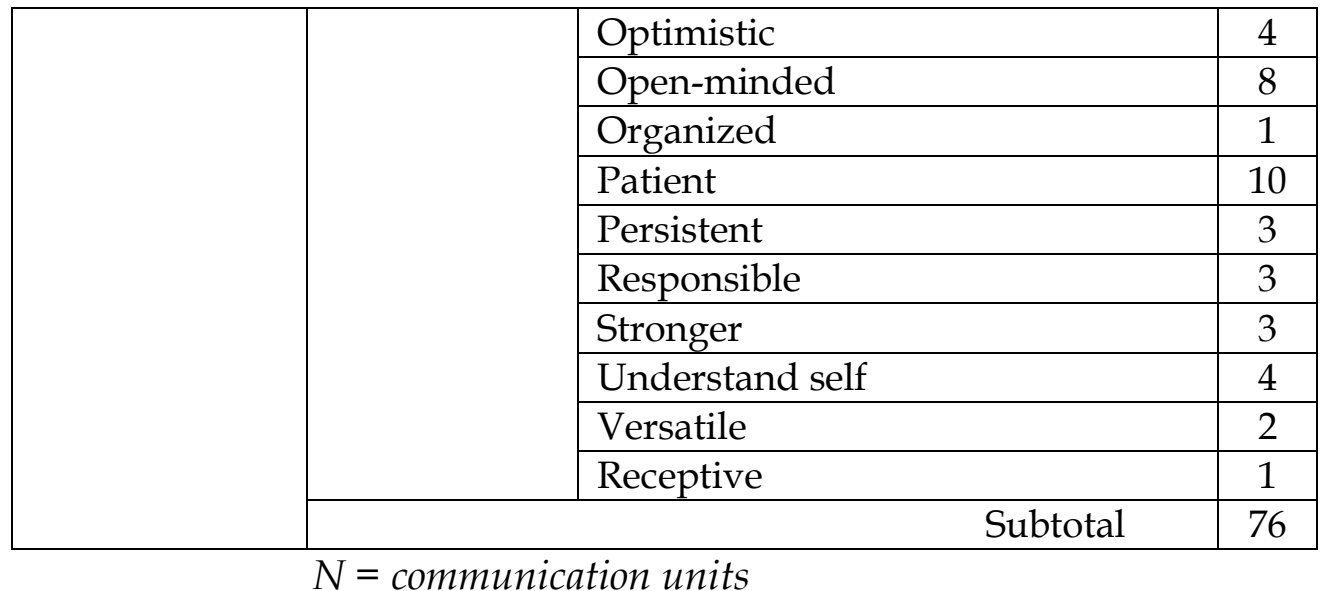

The description that narrates about a self-perceived improvement of growth and development is considered to be significant because it was specially mentioned in the reports. The main category was further subdivided into cognitive and emotional growth. A subcategory is coded as cognitive when the communication unit pertains to growth and development of the mental faculty; it is coded as emotional when the communication unit pertains to growth and development of the affective state. There were more communication units coded for cognitive growth $(\mathrm{N}=35)$ than emotional growth $(\mathrm{N}=76)$.

\section{Cognitive growth}

The subcategory with the highest frequency of communication units is the application of teaching principles and strategies. For example, Maica noticed a significant improvement in herself when:

"I know how to make better lesson plans and execute them properly because I was required to make one every day; I became more eager to explore the various topics in English."

The second highest frequency of communication units under cognitive growth is cognitive preparedness/mastery of the lesson. For instance, Rosebelle realized that:

"teaching a lesson will make you remember a specific topic more than just studying it...indeed one must study like he/she is going to teach it to someone because it's very effective".

\section{Emotional growth}

The subcategory on emotional growth with the highest frequency of communication units is being patient. Josie narrated her bouts with almost losing her patience:

"There was a time when I was so exhausted doing a lot of things all at the same time, and then I saw my cooperating teacher sitting on 
one of the student's chairs doing nothing - I felt irritated; however, I still managed to deliver my lesson well and smile. Practicum has taught me lots of patience."

\section{Perceived effectiveness of the practicum experience}

The analysis of the final reflection reports of the participants reveals a category on the effectiveness of the practicum experience as perceived by the English teacher-interns as presented in Table 3 below.

Table 3. Perceived effectiveness of the practicum experience

\begin{tabular}{|l|l|c|}
\hline \multicolumn{1}{|c|}{ Category } & Sub-category & $\boldsymbol{N}$ \\
\hline \multirow{2}{*}{$\begin{array}{l}\text { Perceived effectiveness of the practicum } \\
\text { experience of the pre-service English } \\
\text { teachers }\end{array}$} & Very Effective & 22 \\
\cline { 2 - 3 } & Quite Effective & 5 \\
\cline { 2 - 3 } & Undecided & 3 \\
\hline \multicolumn{2}{|c|}{ Total } & 30 \\
\hline
\end{tabular}

$N=$ communication units

The data reveals that 22 of the 30 participants $(73.33 \%)$ found their practicum experience "very effective" for integration in their English language teaching while 5 of the participants $(16.66 \%)$ found it to be quite effective. Three participants $(10 \%)$ were not able to clearly describe the effectiveness of their practicum experience as it was not mentioned in the reflection reports for the researcher to code them into communication units.

\section{Discussion}

The results in the previous section show that the pre-service English language teachers demonstrate reflectivity in completing their final journal reports by giving their general impression of the practicum experience. They likewise acknowledged a perceived level of improvement in themselves emotionally and cognitively and provided a thoughtful review of whether their practicum proved to be effective.

\section{General impression of the practicum experience}

A substantive number of the pre-service English language teachers generally reported a positive impression of their practicum experience. This is evidenced by the use of positive evaluative remarks, counted as communication units, like the best thing that ever happened in my life, the most significant part of my education, it was beyond expectations, and so on (see Table 1). The finding supports the study of Alkhawaldeh (2011), where an overwhelming number of the pre-service teacher participants reported that they highly valued the significance of their pre-service training, which, according to them, aids the development of their practice of teaching English.

However, it is apparent that the interns did not give an overwhelming number of positive impression of their practicum experience. Forty-percent reported a negative impression. This negative impression of the practicum 
experience by forty-percent of the participants finds support in some studies (e.g., MacDonald, 1993; Paulus \& Scherff, 2008; cited in Parks, 2009), where a majority of students in these studies found their practicum experience stressful. Understandably, the feelings of stress and anxiety are felt because during practicum, the pre-service teachers needed to fulfill at least two roles: being a good student who has mastered all the theoretical concepts taught in college; and, at the same time, be a good teacher who must translate the theoretical knowledge into practical and experiential learning to the students in their practicum classes.

\section{Self-perceived significant growth during the practicum}

By the process of reflective thinking through the reports, it is surmised that the participants perceived a certain degree of growth considered as significant because they were specially mentioned. There were more communication units coded for cognitive than emotional growth.

\section{Cognitive growth}

The participants indicated that they had grown cognitively during the practicum. Their theoretical preparation took shape in the form of self-concepts in the journals when the pre-service teachers reflected about how they have personally perceived improvements during their practicum. The self-reported cognitive improvements of the participants in themselves place the application of teaching principles and strategies at the top of the list. Just as Gebhard (2009) has mentioned, that teaching practicum leads to gaining practical classroom experience by the application of theory and teaching ideas and the knowledge gained by observing experienced teachers, the participants in the present study has shown recognition of their prospective identities as second language teachers.

\section{Emotional growth}

More communication units indicate emotional growth. Being patient has the most number of communications coded under this sub-category. This is interpreted in the light of the many difficulties that simultaneously enter the sphere of instructional experience the pre-service English teachers face such as, classroom management, time management, cooperating teaching expectations, supervisor expectations, lesson plan preparation, and implementation, etc.

Reporting these self-perceived milestones, pre-service English teachers were able to conceptualize their practicum experience and construct for themselves a knowledge base that interweaves theoretical and experiential knowledge. This identity construction seemingly shapes the pre-service English teachers' belief system that would contribute to instructional benefits especially during the initial teaching stages of the pre-service English teachers.

\section{Perceived effectiveness of the practicum experience of the pre-service English teachers in preparing them for second language teaching}


An overwhelming number of participants considered their practicum experience useful. Ninety-per cent of the participants derived a relative degree of satisfaction that prompted them to report the practicum to be effective. Only three participants were ambivalent, although, they did not say that the practicum was not effective. It is construed that the extended practicum program of two semesters was viewed to have brought acknowledged benefits to the interns who considered them helpful to their experiential preparation. The teacher education program must have afforded the interns a training recognized to have impacted their teacher preparation. This general view by the participants runs counter to the findings in Stuart \& Thurlow (2000) where teacher-interns reported that their preparation in their teacher education program was inadequate to meet the requirement of real-life teaching (cited in Merc, 2010). While it is generally agreed that overcoming the challenges in classroom experiences during practicum is critical when teacher-interns are to go beyond a model that is only dependent on their sphere of observation, researchers argue that teachers' belief extremely resist change (Johnson, 1994). Additionally, pre-service teachers must have direction about learning from their current circumstance rather than for them to solely depend on knowledge for future benefit and consideration (Edge, 2015).

\section{Conclusion}

The current study inferred the pre-service English teachers' conceptualization of their practicum teaching experience from their final reflective reports. It investigated how these conceptualizations of their practicum shaped the way they perceive themselves as prospective English teachers and of English language teaching as well. By an iterative process, the most prominent theme that emerged from the reflections is a positive general impression of the practicum. The interns find their cognitive development more towards the application of teaching principles and strategies. This affirms Grossman's (1992) contention that procedural knowledge occupies the most critical aspect of learning to teach (cited in Hudson et al., 2008). Ethell and McMenimam (2000) share a similar view when they posited that student teachers derive more experiences from classrooms while practice teaching in schools (cited in Hudson et al., 2008).

\section{Limitations of the study}

The empirical results reported should be considered in the light of some limitations. First, the nature of the research design precludes the results from being generalized as in the sense of quantitative studies, but findings may be transferred, in that, the reflections of the participants may help inform the practicum programs across various disciplines. Also, the dataset consisted of only the final reflection reports. Future research may consider including all the reflection journals of the student interns to possibly uncover in-depth data for analysis. 


\section{Implications}

This study inferred the pre-service English language teachers' conceptualizations of their internship experience and investigated the process of reflective identity construction that the interns made from their final reflection reports submitted. Considering that the participants are the pioneer interns to experience an extended practicum of two-semesters instead of the previous one semester, it is implicit that teacher education programs recognize the teachers' emerging identity construction based on reflection.

Interns undertake a thoughtful review of their experiences as they reflect on their instructional practices. This process allows opportunities whereby traditional beliefs on teaching become challenged by inducing the power of reflective thinking. The use of periodic reflection-journals is a step towards this direction. Teacher educators and educational researchers must thoughtfully consider the "ontological problem of reality in their work" to prepare teachers and to study prospective and beginning teachers' lived experiences (Edge, 2015 p. 38).

The present study, too, is valuable to the teacher education program of the institution. It necessitates a process of self-monitoring whereby the institution rethinks its practices. In so doing, it evaluates the strength and weakness of the practicum training it provides to its second language teacherinterns to enhance instruction delivery and make it more responsive to the needs of the second language learners and, ultimately to the demands of the labor market for the highly qualified, trained, competitive, innovative and reflective breed of English language teachers.

\section{References}

Alkhawaldeh, A. (2011). Pre-Service Training of English language Teachers in Jordan: Difficulties and Solutions. European Journal of Social Sciences, Volume 26(1), 98-114.

Berci, M. (2007). The autobiographical metaphor: An invaluable approach to teacher development. The Journal of Educational Thought, 41(1), 63-89.

Constructivism as a Learning Theory (Retrieved April 4, 2018. Retrieved from http://www.learning-theories.com/constructivism.html)

Creswell, J. (2003). Research design: Qualitative, quantitative and mixed methods approaches (2nd ed.). Thousand Oaks, CA: SAGE Publications.

Edge, C. (2015). On the nature of experience in the education of prospective teachers: A Philosophical Problem, International Journal of Learning, Teaching and Educational Research 13(1), 29-41.

Farrell, T. S. C. (1999). Teachers talking about teaching: creating conditions for reflection. TESL-EJ, 4(2), 1-14.

Gebhard, J. (2009). The practicum. In A. Burns, \& J. Richards (Eds.), The Cambridge guide to second language teacher education, 250-258. Cambridge: Cambridge University Press.

Goker, S. D., 2006. Impact of peer coaching on self-efficacy and instructional skills in TEFL teacher education, Elsevier System 34, 239-254. 
Hudson, P., Nguyen, T. M. \& S. Hudson. (2008). Challenges for preservice EFL teachers entering practicum. In Proceedings 2008 Asia TEFL International Conference:Globalizing Asia: The Role of ELT, Bali, Indonesia.

Johnson, K. (1994). Emerging beliefs and instructional practices of pre-service English as a second language teachers, Teachina \& Teacher Education, 10(4), 439-452.

Liou, H. C. (2001). Reflective practice in a pre-service teacher education program for high school. English teachers in Taiwan, ROC. System, 29, 197-208.

Loeb, S., Dynarski, S., McFarland, D., Morris, P., Reardon, S., \& Reber, S. (2017). Descriptive analysis in education: A guide for researchers. Washington, DC: U.S. Department of Education, Institute of Education Sciences, National Center for Education Evaluation and Regional Assistance.

Merc, A. (2010). Self-Reported Problems of Pre-Service EFL Teachers throughout Teaching Practicum. Anadolu University Journal of Social Sciences, 10(2), 199-226.

Parks, S. (2009). A WebCT Discussion Forum during a TESL Practicum: Pre-service Teachers' Perceptions of Learning. Canada Journal of Applied Linguistics. 52-70.

Spooner-Lane, R., Tangen D. \& M. Campbell. (2009). The complexities of supporting Asian international pre-service teachers as they undertake practicum. AsiaPacific Journal of Teacher Education, 37(1), 79-94.

Trent, J. (2010). "My Two Masters": Conflict, Contestation, and Identity Construction Within a Teaching Practicum, Australian Journal of Teacher Education, 35(7), 1-14.

Wang, J. \& Odell, S. J. (2003). Learning to teach toward standards-based writing instruction: Experiences of two preservice teachers and two mentors in an urban, multicultural classroom. The Elementary School Journal, 104(2), 147-174.

Yang, S. H. (2009). Using Blogs to Enhance Critical Reflection and Community of Practice. Educational Technology \& Society, 12(2), 11-21. 